\section{International Scientific Journal Theoretical \& Applied Science}

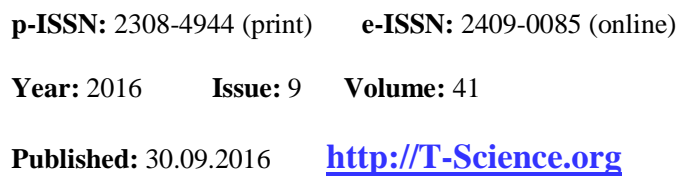

SECTION 31. Economic research, finance, innovation, risk management.
Liazzat Sihymbaieva Muster student of Kazakh Engineering and Pedagogical University of Nations Friendship

Aigul Kuanyshevna Kupesheva Candidate of economical science, Chief of department of Kazakh Engineering and Pedagogical University of Nations Friendship

Ersultan Zhomartovich Shalkhar Muster student of Kazakh Engineering and Pedagogical University of Nations Friendship

Nurlan Muhtarovich Batyrbaev Candidate of law science, professor Vice president of International Kazakh-

Turkish University after H.A.Yessevi

Erkin Shazhievich Dusipov

Doctor of law science, professor Zhetysu state University after I.Zhansugurov

Yernar Sailaubekovich Shalkharov Master of law, economics, bachelor Of biology. Corresponding member Of Theoretical and Applied Science Academy. General director of BeinAgroIndustries LTD yernar_shalkharov@bk.ru

\title{
S.W.O.T ANALYSIS OF SMALL BUSINESS DEVELOPING STRATEGY IN A MARKET ECONOMY CONDITIONS FROM THE POSITION OF INNOVATIONS
}

\footnotetext{
Abstract: In developing the era of market economy any state tends to develop small business sector in the first place. After all, small business is a catalyst for the progress of the national economy both at micro level and at the macro level. In such a trend the most important factor is the chosen strategy of development of small business in the marketplace state territorial unit.

Key words: profitability, government, rental strategy, small business, S.W.O.T analyses, decision, consumer, good.

Language: English

Citation: Sihymbaieva L, Kupesheva AK, Shalkhar EZ, Batyrbaev NM, Dusipov ES, Shalkharov YS (2016) S.W.O.T ANALYSIS OF SMALL BUSINESS DEVELOPING STRATEGY IN A MARKET ECONOMY CONDITIONS FROM THE POSITION OF INNOVATIONS. ISJ Theoretical \& Applied Science, 09 (41): 145148.

Soi: http://s-o-i.org/1.1/TAS-09-41-23 Doi: crossef http://dx.doi.org/10.15863/TAS.2016.09.41.23
}

\section{Introduction}

Development of small and medium-sized businesses at all times was considered the basis for economic development of the state. But the development of small and medium-sized businesses is, first and foremost, an educational framework which takes into account all the problems of small business development [1].

Continuous improvement of such a framework will identify and predefine business prospects. It is on the basis of the business development strategy 
designed and in particular the development of Russian business. Development of small and medium business, as the experience of the leading economic powers, leads to an increase in the state's economy as a whole and, ultimately, to improve the welfare of its citizens [2].

Sustainable development of small and mediumsized businesses due to a number of advantages, which it has. And above all, the development of small and medium-sized businesses, is its mobility and flexibility to respond quickly to market demands and quickly adapt to changing conditions [3].

\section{Materials and Methods}

Strategy selection is made according to certain criteria, which are in the rankings the decisive role is played by the top leaders of the organization. Multiple strategies that use the firm, are only a few modifications of the basic strategies. Each of them is effective under certain conditions and the state of the environment [4]. The concept of basic competitive strategy characterizes the kind of competitive advantage and the scope in which it is achieved.

The strategy involves a complex change in the company, without which it is impossible to achieve success, even with an effective strategy. Implementation of changes - is the foundation of the strategy. Under the changes in the organization understand the decision of its leadership to make changes to one or more of the internal components of the organization relating to the goals, objectives, structure, technology, the human factor, which is caused by changes in the external or internal environment [5].

For the survival of the organization of its management should periodically evaluate and adjust the strategic goals and objectives in accordance with the changes in the external environment and the organization itself. Often the need to change the target detected by the monitoring system [6].

Most people decide to start their own business initially used their own strategies based on experience in the business at the most primitive level. This is evidenced by statistics, unfortunately, she is relentless. Each year, bankrupt $90 \%$ of new firms. We offer a 7-purpose strategic development of tactics that can be applied today and in the shortest possible time to succeed in the development of small businesses. Here we will talk about ways to help grow your small business in today's competition [7].

At this stage, the enterprise market position, identify strategic objectives, alternative ways (strategies) to address them. In order to become the strategy, this set of problems and challenges must turn in: all activities should be focused on longterm goals, linked by resources and time, as well as the need to effectively combine and complement each other in terms of the objectives of structural divisions of the company [8].

Together with the definition of a common, corporate strategy development takes place in support of its business strategies and functional strategies. At the heart of a successful strategy should be based on the creation and use of competitive advantages [9]. This may be the ability to sell products at low prices, and providing high quality products and range of services, and advantageous location of the company or its affiliates [10]. This means that the strategy must not only maintain its competitive advantage, but also to initiate new ones [11].

The potential of the company is a collection of its capacity for the production of goods and provision of services and include internal variables and management capacity. The possibility of organizing its predefined resources (factors of production) at its disposal. In a market economy potential of the organization depends on internal factors, as well as on consumer demand, the actions of competitors, the economic situation in the country and others [12].

The competitiveness of the company characterizes its ability to withstand competitors to effectively compete for markets. The competitiveness of firms is a relative characteristic, determined by comparing the object. The factors that determine the competitiveness of the company, are the potential of the company (Resource and Innovation), a skilful choice of strategy, the potential of its senior management, the financial results of its operations [13].

Tactics improve their own standards of quality management should be applied to all kinds of strategies, so it is in the first place. If the level of quality control standard higher than the competitor you have a huge advantage. Develop self-discipline and win their competitors by working on yourself. In all strategies, it is important to manage the resources, and resources are available at all the only question is: how to manage them? All four of the above listed rules will earn, if it is designed to manage and mutual support staff on the principle of synergy [14].

\section{Conclusion}

Perceive the visual design elements Sensor detection as an investment in attracting additional customers. The logo of your brand should not be a work of art, his task is to convey the theme "message" to the target consumers. Qualitatively taken aback products are regularly updated in the 
price range and price. Maximum fill in contact information, add the service "Order a free call." Check the correct display of the site in different browsers on different devices (PCs, tablets, mobile phones). Clients meet your business on clothes. Plan a small project to develop the image and popularity of local businesses [15].

\section{Background.}

For a whole competent it is actual to notice that all issues in articles were formulated from the surveys of BeinAgroIndustries LTD. Also, it is important to mention together work of two university staff: Kazakh Engineering and Pedagogical University of Nations Friendship and International Kazakh-Turkish University after Khoga Akhmet Yassavi. In case of novelty, p.t.value the main author is the last in the list of authors.

\section{References:}

1. Ahsan Habib, Mostafa Monzur Hasan (2016) Business strategy, overvalued equities, and stock price crash risk. Original Research Article Research in International Business and Finance, Volume 39, Part A, January 2016, Pages 389-405.

2. Tobias Johansson, Johan Kask (2016) Configurations of business strategy and marketing channels for e-commerce and traditional retail formats: A Qualitative Comparison Analysis (QCA) in sporting goods retailing. Original Research Article. Journal of Retailing and Consumer Services, In Press, Corrected Proof, Available online 10 September 2016.

3. Jana Poláková, Pavel Moulis, Gabriela Koláčková, Ivana Tichá (2016) Determinants of the Business Model Change - A Case Study of a Farm Applying Diversification Strategy. Original Research Article. Procedia - Social and Behavioral Sciences, Volume 220,31 May 2016, Pages 338-345.

4. Mohammadreza Arasti, Mahdi Khaleghi, Javad Noori (2016) Corporate-level technology strategy and its linkage with corporate strategy in multi-business companies: IKCO case study. Original Research Article. Technological Forecasting and Social Change, In Press, Corrected Proof, Available online 28 March 2016.

5. Daniel I. Prajogo (2016) The strategic fit between

innovation strategies and business environment in delivering business performance. Original Research Article. International Journal of Production Economics, Volume 171, Part 2, January 2016, Pages 241-249.

6. Shaomin Li (2016) Chapter 8 Business Strategies in East Asia. East Asian Business in the New World, 2016, Pages 103-116.
7. Jeff S. Johnson, Ravipreet S. Sohi( 2016) Getting business-to-business salespeople to implement strategies associated with introducing new products and services. Original Research Article. Industrial Marketing Management, In Press, Corrected Proof, Available online 31 August 2016.

8. Jarunee Wonglimpiyarat (2016) The innovation incubator, university business incubator and technology transfer strategy: The case of Thailand. Original Research Article. Technology in Society, Volume 46, August 2016, Pages 18-27.

9. Vasco Reis, João Silva (2016) Assessing the air cargo business models of combination airlines. Original Research Article. Journal of Air Transport Management, Volume 57, October 2016, Pages 250-259.

10. Nancy M.P. Bocken, Alison Fil, Jaideep Prabhu (2016) Scaling up social businesses in developing markets. Original Research Article. Journal of Cleaner Production, Volume 139, 15 December 2016, Pages 295-308.

11. Thayla T. Sousa-Zomer, Paulo A. Cauchick Miguel (2016) Sustainable business models as an innovation strategy in the water sector: An empirical investigation of a sustainable productservice system. Original Research Article. Journal of Cleaner Production, In Press, Corrected Proof, Available online 15 July 2016.

12. Leonidas C. Leonidou, Thomas A. Fotiadis, Paul Christodoulides, Stavroula Spyropoulou, Constantine S. Katsikeas (2015) Environmentally friendly export business strategy: Its determinants and effects on competitive advantage and performance. Original Research Article. International Business Review, Volume 24, Issue 5, October 2015, Pages 798-811.

13. Hashem Aghazadeh (2015) Strategic Marketing Management: Achieving 


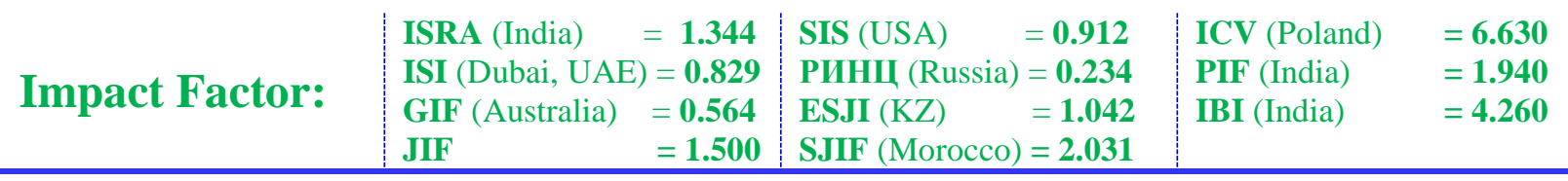

Superior Business Performance through Intelligent Marketing Strategy. Original Research Article. Procedia - Social and Behavioral Sciences, Volume 207, 20 October 2015, Pages 125-134.

14. Kum Fai Yuen, Vinh V. Thai, Yiik Diew Wong. (2016) The effect of continuous improvement capacity on the relationship between of corporate social performance and business performance in maritime transport in Singapore. Original Research Article. Transportation Research Part E: Logistics and Transportation Review, Volume 95, November 2016, Pages 62-75. 